\title{
THE INFLUENCE OF Ag ADDITION ON THE SUPERCONDUCTING PROPERTIES OF Bi(Pb)SrCaCuO CERAMICS
}

\author{
V. Micevski ${ }^{1}$, V. Lovchinov ${ }^{2}$, Z. Milosavlevski ${ }^{1}$, S. Stoimenov ${ }^{1}$ \\ ${ }^{1}$ Institute of Physics, Faculty of Natural Sciences and Mathematics \\ St. St. Cyril and Methodius State University, P.O. Box 162, 1000, Skopje, R. Macedonia \\ ${ }^{2}$ G. Nadjakov Institute of Solid State Physics, Bulgarian Academy of Sciences \\ 72 Tzarigradsko Chaussee Blvd., BG-1784 Sofia, Bulgaria \\ (Received August 30, 2001; received in final form October 2, 2001)
}

\begin{abstract}
The influence of different silver amount $(7.5,10,12$, and $15 \mathrm{wt} . \%)$ added as $\operatorname{Ag}_{2} \mathrm{O}$ to the initial $\mathrm{Bi}(\mathrm{Pb}) \mathrm{SrCaCuO}$ precursor on the phase formation, microstructure and superconducting properties of the bulk samples was investigated. The degree of the intergranular diffusion of the silver and its role on the (2223) phase formation, alignment and connection of the (2223) grains were studied using $\mathrm{X}$-ray diffraction, AC-susceptibility measurement and scanning electron microscopy, respectively.

Key words: $\mathrm{Bi}(\mathrm{Pb}) \mathrm{SrCaCuO}$ ceramics; Ag doping; x-ray diffraction; magnetic properties; phase formation
\end{abstract}

PACS number(s): 74.20.-z, 05.10.Cc, 11.25.Hf

\section{INTRODUCTION}

For the practical application of high temperature superconductors, the main important property is their current carrying capacity and its field and temperature dependence. At the current moment, the most promising compound is the $\mathrm{Bi}(\mathrm{Pb}) \mathrm{SrCaCuO}$ system. Silver sheathed superconducting tapes, produced from this system have been reported to obtain critical current density $\left(J_{\mathrm{c}}\right)$ of more than $10^{4} \mathrm{~A} / \mathrm{cm}^{2}$ at $77 \mathrm{~K}(0 \mathrm{~T})[1,2]$, and $10^{5} \mathrm{~A} / \mathrm{cm}^{2}$ at $4.2 \mathrm{~K}(10 \mathrm{~T})[3,4]$, respectively. OxidePowder-In-Tube (OPIT) technique is at the moment the most promising technology for the preparation of tapes with a high critical current density. The first stage in this procedure is the prepartion of the superconducting $\mathrm{Bi}(\mathrm{Pb}) \mathrm{SrCaCuO}$ powder with good quality.

Now it is well known that silver has been successfully used as a doping material to make the $\mathrm{Bi}-\mathrm{Pb}-\mathrm{Sr}-$ $\mathrm{Ca}-\mathrm{Cu}-\mathrm{O}$ system more suitable for practical application. The silver added to the initial ( $\mathrm{Bi}, \mathrm{Pb})_{2} \mathrm{Sr}_{2} \mathrm{Ca}_{2} \mathrm{Cu}_{3} \mathrm{O}_{10}$ $(\mathrm{Bi}(\mathrm{Pb}) \mathrm{SCCO}$ ) precursor was found to accelerate the formation process of high superconducting (2223) phase [5], improve the orientation of the 2223 grains and its connectivity [6] and enhance the level of the tensile strain and strain tolerance of the samples [7]. All these advantages resulting in critical current density improvement make the investigations connected with the silver doping effect on the properties of the $\mathrm{Bi}-\mathrm{Pb}-\mathrm{Sr}-\mathrm{Ca}-\mathrm{Cu}-\mathrm{O}$ system very important. Moreover, up to now there has been no effective physical model to understand the behaviour of silver in this system.

In the present work we investigate the effect of different silver amount additives $(7.5,10,12$ and $15 \mathrm{wt} . \%)$ on the superconducting properties of the $\mathrm{Bi}(\mathrm{Pb}) \mathrm{SCCO}$ system. This allows to elucidate not only the qualitative effect of Ag additive but will help to optimize its quantity, also. In this study the silver doping effect on critical temperature $T_{c}$, critical current density $J_{c}$ and magnetic susceptibility $\chi$ are reported. The observed change of these properties will be explained by the results of microstructural analyses and X-ray diffraction measurements.

\section{EXPERIMENT}

The investigated samples were made by mixing of constituent oxides and carbonates: $\mathrm{Bi}_{2} \mathrm{O}_{3}, \mathrm{PbO}_{2}, \mathrm{SrCO}_{3}$, $\mathrm{CaCO}_{3}, \mathrm{CuO}$ in the atomic ratio $\mathrm{Bi}: \mathrm{Pb}: \mathrm{Sr}: \mathrm{Ca}: \mathrm{Cu}$ $=1.7: 0.3: 2: 2: 3$ and $7.5,10,12$, and 15 wt. $\%$ added as $\mathrm{Ag}_{2} \mathrm{O}$ to the initial $\mathrm{Bi}_{1.7} \mathrm{~Pb}_{0.3} \mathrm{Sr}_{2} \mathrm{Ca}_{2} \mathrm{Cu}_{3} \mathrm{O}_{10+x}$ precursor. The weighted powders were thoroughly mixed by a ball mill in an agate container for $2-3 \mathrm{~h}$. After pressed into cylindrical pellets, the samples were sintered at $800^{\circ} \mathrm{C}$ for $24 \mathrm{~h}$ in air atmosphere. The pellets were then grounded in powder, repressed in pellets and annealed at $838^{\circ} \mathrm{C}$ for $200 \mathrm{~h}$ in air. Finally, the samples were cooled down to the room temperature. The heating and cooling rate were $10^{\circ} \mathrm{C} / \mathrm{min}$ and $1^{\circ} \mathrm{C} / \mathrm{min}$, respectively.

The phase composition and degree of texture of the samples were determined by X-ray diffraction (XRD) using a DRON-3 diffractometer with $\mathrm{Cu}-\mathrm{K}_{\alpha}$ radiation. Scanning Electron Microscopy (SEM) analyses were performed in order to identify the secondary phases and to obtain a better estimation of their size and distribution with increasing amount of the silver additives. Scanning electron micrograph Philips with 7000 times magnification is used for the SEM analyses.

Two different methods are used for determination of critical temperature $T_{c}$, critical current $I_{c}$ and broadening of the superconducting transition $\Delta T_{c}$. For electrical measurements standard four probe technique with $1 \mu \mathrm{V} \cdot \mathrm{cm}^{-1}$ criterion was used, whereas for magnetic measurements a method of mutual inductance of two opposite-wound identical coils were applied. The critical current density value $J_{c}$ was determined from the $I_{c}$ using the area of the cross section of the samples. For this purpose the final geometry of the samples were in form 
of the bar $\left(S=1 \mathrm{~mm}^{2}\right)$. The resistance is normalized to the value measured at $T=150 \mathrm{~K}$.

\section{RESULTS AND DISCUSSION}

Fig. 1 summarizes XRD patterns of the samples without $\mathrm{Ag}(\mathrm{A})$ and with different amounts of silver additives $(\mathrm{B}-7.5, \mathrm{C}-10, \mathrm{D}-12$, and $\mathrm{E}-15$ wt.\% Ag). The major peaks in all the patterns can be indexed with the high (2223) phase. It can be seen from this figure that, samples without silver and with $7.5 \mathrm{wt} . \% \mathrm{Ag}$ show additional peaks corresponding to the 2212 phase and to $(\mathrm{Ca}, \mathrm{Sr})_{2} \mathrm{CuO}_{3}$ compound. Further increasing of the amounts of silver additive leads to the disappearance of $(\mathrm{Ca}, \mathrm{Sr})_{2} \mathrm{CuO}_{3}$ compound and partial conversion of the 2212 phase into 2223 one. It is obvious that 2223 peak intensities increase and the 2223 phase becomes progressively dominant, indicating $c$-axes alignment of the 2223 grains with increasing the silver amounts. This process is in progress up to $12 \mathrm{wt} . \% \mathrm{Ag}$ addition, after which no substantial differences are observed.

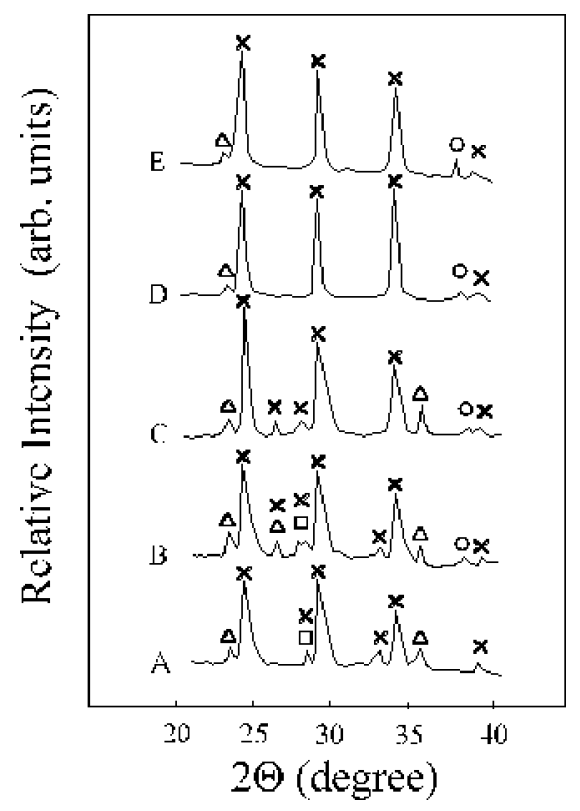

Fig. 1. XRD patterns of oxide samples with different amounts of $\mathrm{Ag}$ additives: $\times-2223 \mathrm{BSCCO}$ phase; $\square-$ $(\mathrm{Ca}, \mathrm{Sr})_{2} \mathrm{CuO}_{3} ; \triangle-2212 \mathrm{BSCCO}$ phase; o - silver; $\mathrm{A}-$ sample without $\mathrm{Ag}$ additive; $\mathrm{B}-$ with $7.5 \% \mathrm{Ag} ; \mathrm{C}-10 \%$ Ag; D $-12 \%$ Ag; E - 15\% Ag.

On Fig. 2 by SEM measurements the favourable role of the silver additives on the microstructure, grain alignment and better connectivity between the grains is demonstrated. Fig. 2, a shows undoped B(Pb)SCCO sample, whereas Figs. 2,b,c and 2,d are the SEM images for the samples doped with $7.5,12$ and 15 wt.\% Ag, respectively. It can be seen in Fig. 2,a, that the undoped sample is more porous with widely distributed secondary phases. After doping with 7.5 wt.\% Ag (Fig. 2,b) the density and the amount of the 2223 phase become substantial but the size of secondary particles does not change (dark blocks in Fig. 2,b). A further enhancement of the amount of the silver additive leads to the reduction in the secondary particle sizes but the small silver particles tend to agglomerate into large ones, which are not desired for either grain orientation or flux pinning (Figs. 2,c,d).

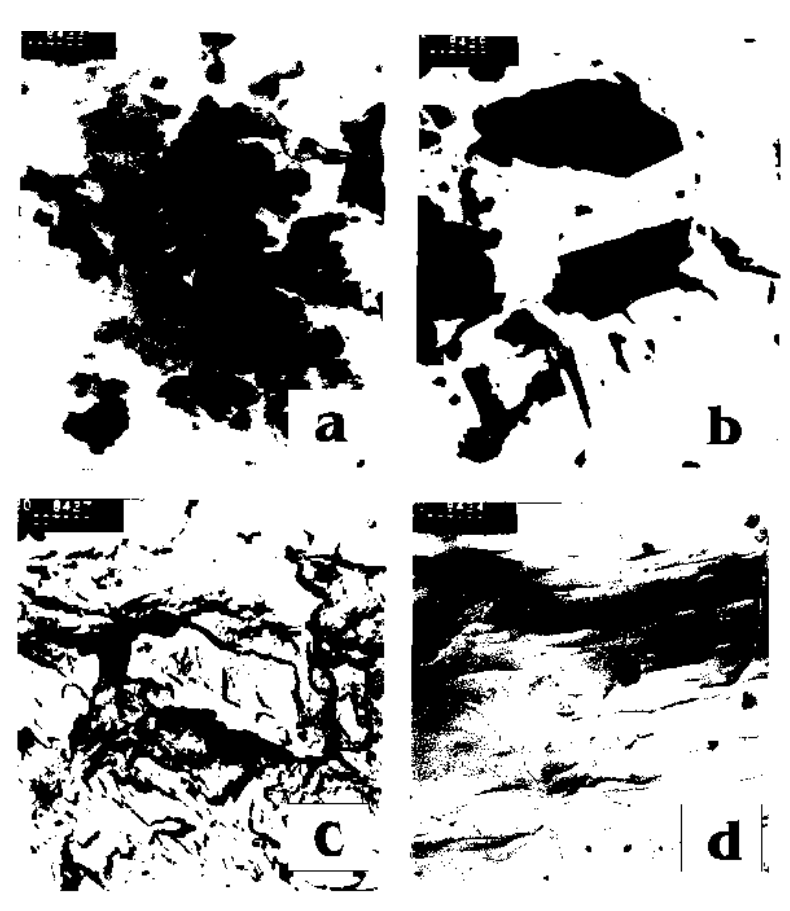

Fig. 2. SEM micrographs showing the morphology of the samples: (a) without $\mathrm{Ag}$, (b) with $7.5 \mathrm{wt} . \% \mathrm{Ag}$, (c) with 12 wt.\% Ag, and (d) with 15 wt.\% Ag.

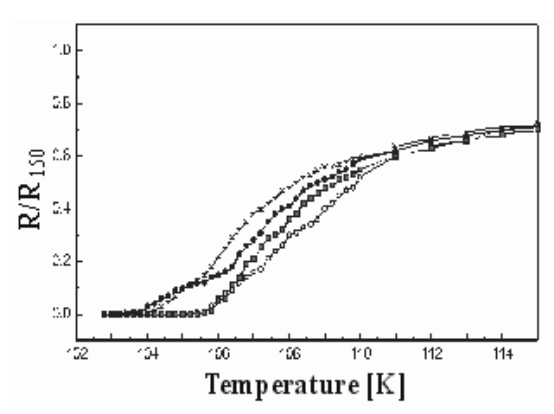

Fig. 3. Temperature dependence of the normalized resistence: o - $0 \mathrm{wt} . \% \mathrm{Ag} ; \mathbf{\square}-7.5 \mathrm{wt} . \% \mathrm{Ag} ; \bullet-$ for 12 wt.\% Ag; $\times-15$ wt. $\%$ Ag.

In order to investigate the influence of silver doping on the electrical and magnetic properties of the BSCCO samples the temperature dependence of the resistance $R(T)$ and both real $\chi^{\prime}$ and imaginary $\chi^{\prime \prime}$ parts of the 
magnetic susceptibility were measured. Figs. 3 and 4 show $R(T), \chi^{\prime}(T)$ and $\chi^{\prime \prime}(T)$ results for undoped and for some doped samples (7.5, 12 and $15 \mathrm{wt} . \% \mathrm{Ag})$ which show the tendency of these measurements.

The analyzing of the curves $R(T) / R_{150}$ presented in Fig. 3 affirm that in all the samples the zero resistance temperature is above $100 \mathrm{~K}$ which signifies dominant presence of high temperature superconducting 2223 phase. The results affirm that the addition of $\mathrm{Ag}_{2} \mathrm{O}$ in $\mathrm{Bi}_{1.7} \mathrm{~Pb}_{0.3} \mathrm{Sr}_{2} \mathrm{Ca}_{2} \mathrm{Cu}_{3} \mathrm{O}_{10+x}$ (7.5 and $\left.10 \mathrm{wt} . \%\right)$ have resulted in increasing of $T_{C}$ and narrowing of $\Delta T$ which is in agreement with the results reported in $[6,8,9]$. In the samples with large addition of $\mathrm{Ag}_{2} \mathrm{O}$ (12 and 15 wt.\%) the resistance transition broadening and the slow approach to the zero resistance state are registrated. This signifies the suppression of the order parameter in the grain boundary region [10].

The temperature dependence of the AC susceptibility presented in Fig. 4 gives the results which are in a good agreement with $R(T)$ one. As can be seen the onset of diamagnetism (curves $\chi^{\prime}$ ) and the energy loss peaks (curves $\chi^{\prime \prime}$ ) for all the samples start at almost the same temperatures determined from $R(T)$ measurements. The $\chi^{\prime}$ curves became slightly broader with increasing of $\mathrm{Ag}$ additives. For all the samples in the transition region a small kink is registrated. A deeper insight can be obtained by analyzing the behaviour of $\chi^{\prime \prime}$ as a function of the temperature and Ag amount. These curves exhibit two peaks. From these facts it can be inferred that $\mathrm{Ag}$ additives do not eliminate differences between the interand intragrain current even though they promote the intragrain contacts and texturing of the samples.

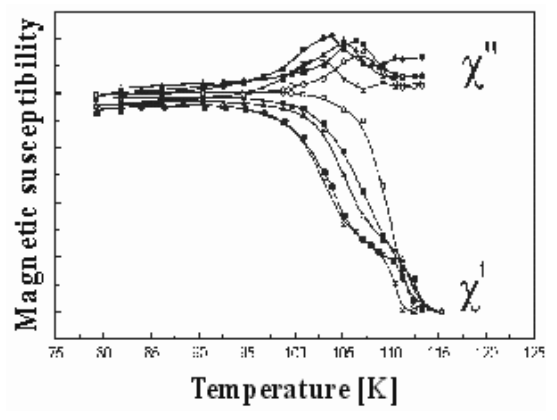

Fig. 4. Temperature dependence of the madnetic susceptibility: ○-0 wt.\% Ag; $-7.5 \mathrm{wt} . \% \mathrm{Ag} ; \triangle-10 \mathrm{wt} \% \mathrm{Ag}$; - - for 12 wt.\% Ag; $\times-15$ wt. $\% \mathrm{Ag}$.

All this explains very low values of $J_{c}$ which are presented in Table 1 . Here are summarized also the parameters: critical temperature $T_{c}$, zero resistance temperature $T_{0}$, onset temperature $T_{\text {ons }}$ and broadening of the resistance transition.

\begin{tabular}{|l|l|l|l|l|l|}
\hline \multirow{2}{*}{ Samples } & \multicolumn{5}{|c|}{ Characteristics } \\
\cline { 2 - 7 } & $T_{c}[\mathrm{~K}]$ & $T_{0}[\mathrm{~K}]$ & $T_{\text {ons }}[\mathrm{K}]$ & $\Delta T[\mathrm{~K}]$ & $J_{c} \cdot 10^{2} \mathrm{~A} / \mathrm{cm}^{2}$ \\
\hline o- BSCCO & $105.5(105)$ & $104(103)$ & $109(110)$ & $5(7)$ & 0.3 \\
\hline $\mathbf{a}-\mathrm{BSCCO}+7.5 \mathrm{Ag}$ & $107(107)$ & $106(105)$ & $110(112)$ & $4(7)$ & 0.5 \\
\hline$\triangle-\mathrm{BSCCO}+10 \mathrm{Ag}$ & $106(105.5)$ & $105(102)$ & $110.5(111)$ & $5.5(9)$ & 1.2 \\
\hline$\bullet-\mathrm{BSCCO}+12 \mathrm{Ag}$ & $106(105)$ & $104(101)$ & $109.5(110)$ & $5.5(9)$ & 0.2 \\
\hline$\times-$ BSCCO+15 Ag & $105(104)$ & $103(100)$ & $109(109)$ & $6(9)$ & 0.02 \\
\hline
\end{tabular}

Table 1. Characteristics of the Ag doped and undoped samples, obtained by $R(T)$ and $\chi(T)$ (in brackets) measurements.

\section{CONCLUSION}

The effects of silver added as $\mathrm{Ag}_{2} \mathrm{O}$ to the initial a BSCCO precursor on the phase formation, microstructure and superconducting properties of the bulk samples are studied. The Ag additive is found to refine the secondary particles and accelerate the formation process of high superconducting 2223 phase. When the additives are below $10 \mathrm{wt} . \% \mathrm{Ag}$ an improvement of the 2223 grains orientation was observed, which brings to an additional enhancement in $T_{c}$ and $J_{c}$. With increasing of the amount of silver additive (more than 10\%) the grain misorientation becomes more pronounced resulting in $J_{\mathrm{c}}$ degrada- tion.

The main achievement of this investigation is the conclusion that no more than $10 \mathrm{wt} . \% \mathrm{Ag}$ additive is necessary to produce BSCCO precursor as a starting material with good initial parameters for the preparation of superconducting Ag-sheathed tapes.

\section{ACKNOWLEDGEMENTS}

The authors are grateful to Prof. D. A. Dimitrov for helpful discussion and to Prof. E. Kaschieva for XRD and SEM measurements. 
[1] Y. Yamada, B. Obst, R. Flukiger, Supercon. Sci. Technol. 4, 165 (1991).

[2] Q. Li, K. Brodersen, H. A. Hjuler,T. Freltoft, Physica C 217, 360 (1993).

[3] Y. Yamada, M. Satou, S. Murase, T. Kitamura, Y. Kamisada, in Proceedings of 5th Internacional Symp. on Superconductivity (ISS“92) (Kobe, Japan, 1992) p. 717 .

[4] Y. Kamisada, T. Koirumi, M. Satou, Y. Yamada, IEEE Trans. Magn. 30, 1675 (1994).

[5] Y. C. Guo, H. K. Liu, S. X. Dou, Materials Lett. 18, 336 (1994).
[6] J. P. Singh, J. Joo, N. Vasanthamohan, R. B. Poepe, J. Mater. Res. 8, 2458 (1993).

[7] J. W. Ekin, D. K. Finnemore, Q. Li, J. Tenbrink, W. Carter, Appl. Phys. Lett. 61, 17 (1992).

[8] V. Lovchinov, G. Kallias, E. Moraitakis, D.Niarchos, D. Dimitrov, A. Stoyanova, P. Simeonova, I. Iordanov, M. Pissas, Proc. Suppl. Balkan Phys. Lett. 5, 720 (1997).

[9] K. Matsuraki, K. Shimizu, A. Inoue, T. Masumoto, Materials Lett. 30, 97 (1997).

[10] E. Mezzeti, R. Gerbaldo, L. Gozzelino, B. Minetti, Phys. Rev. B 10, 7623 (1999).

\title{
ВПЛИВ ДОДАВАННЯ Аg НА НАДПРОВІДНІ ВЛАСТИВОСТІ $\mathrm{Bi}(\mathrm{Pb}) \mathrm{SrCaCuO}$ KEPAMIK
}

\author{
В. Міцевскі ${ }^{1}$, В. Ловчінов ${ }^{2}$, З. Мілосавлевскі ${ }^{1}$, С. Стоіменов ${ }^{1}$ \\ ${ }^{1}$ Інститут фізики, факультет природничих наук та математики, \\ Держсавний університет Сб. Кирила і Мефодія,$$
\text { P. О. Вох, 162, 1000, Скоn'е, Македонія }
$$ \\ ${ }^{2}$ Iнститут фізики твердого стану Г. Нод'якова, Болгарсъка академія наук, \\ 72, буль. ПІаръградско шосе, $B G-1784$, Софія, Болгарія
}

Досліджено вплив різної кількости срібла (7.5, 10, 12, and 15 wt.\%), що додається як Аg $_{2} \mathrm{O}$ до початкового $\mathrm{Bi}(\mathrm{Pb}) \mathrm{SrCaCuO}$, на формування фази, мікроструктуру та надпровідні властивості об'ємних зразків. Було вивчено ступінь міжтранулярної, дифузії срібла та його вплив на формування фази (2223), вирівнювання і зв'язок гранул (2223) за допомогою відповідної рентгенівської дифрактії, вимірювань АСсприйнятливости та дослі,тження за допомогою елекронного мікроскопа. 